\title{
Susceptibility to Oxidative Stress Is Determined by Genetic Background in Neuronal Cell Cultures
}

\author{
[D Mattias Günther, ${ }^{1}$ [DFaiez Al Nimer, ${ }^{2}$ Fredrik Piehl, ${ }^{2}$ Mårten Risling, ${ }^{1}$ and ${ }^{\circledR}$ Tiit Mathiesen ${ }^{2}$
}

DOI:http://dx.doi.org/10.1523/ENEURO.0335-17.2018

${ }^{1}$ Department of Neuroscience, Karolinska Institutet, Stockholm, Sweden, ${ }^{2}$ Department of Clinical Neuroscience, Karolinska Institutet, Stockholm, SE-171 77, Sweden

\begin{abstract}
Traumatic brain injury (TBI) leads to a deleterious and multifactorial secondary inflammatory response in the brain. Oxidative stress from the inflammation likely contributes to the brain damage although it is unclear to which extent. A largely unexplored approach is to consider phenotypic regulation of oxidative stress levels. Genetic polymorphism influences inflammation in the central nervous system and it is possible that the antioxidative response differs between phenotypes and affects the severity of the secondary injury. We therefore compared the antioxidative response in inbred rat strains dark agouti (DA) to piebald viral glaxo (PVG). DA has high susceptibility to inflammatory challenges and PVG is protected. Primary neuronal cell cultures were exposed to peroxynitrite $\left(\mathrm{ONOO}^{-}\right)$, nitric oxide (NO), superoxide $\left(\mathrm{O}_{2}^{-}\right)$, and 4-hydroxynonenal (4-HNE). Our findings demonstrated a phenotypic control of the neuronal antioxidative response, specific to manganese $\mathrm{O}_{2}^{-}$dismutase (MnSOD). DA neurons had increased levels of MnSOD, equal levels of peroxiredoxin 5 (PRDX5), decreased oxidative stress markers 3-nitrotyrosine (3-NT) and 4-HNE and decreased neuronal death detected by lactate dehydrogenase $(\mathrm{LDH})$ release after $24 \mathrm{~h}$, and higher oxidative stress levels by CellROX than PVG after $2 \mathrm{~h}$. It is possible that DA neurons had a phenotypic adaptation to a fiercer inflammatory environment. ONOO ${ }^{-}$was confirmed as the most powerful oxidative damage mediator, while 4-HNE caused few oxidative effects. Inducible NO synthase (iNOS) was not induced, suggesting that inflammatory, while not oxidative stimulation was required. These findings indicate that phenotypic antioxidative regulation affects the secondary inflammation, which should be considered in future individualized treatments and when evaluating antioxidative pharmacological interventions.
\end{abstract}

Key words: oxidative stress; neuronal inflammation; traumatic brain injury; cell culture; Dark Agouti; Piebald Viral Glaxo

\section{Significance Statement}

Neurotrauma leads to inflammation and oxidative stress in the brain. The outcome differs between individuals, and it is largely unknown what causes this diversity. It is possible that the brain phenotype is linked to oxidative stress levels, and that some individuals acquire less oxidative stress than others. We therefore tested the oxidative stress reaction patterns in rat neurons from two strains with different susceptibility to inflammation. We found that the phenotypes have different regulation of antioxidative enzymes and oxidative stress. While further studies are needed to corroborate the findings in vivo, it is a proof of concept of genetic regulation of direct oxidative stress, which may impact outcome after TBI and interact with future antioxidative treatment trials.

Received July 12, 2017; accepted February 18, 2018; First published March 9, 2018.

The authors declare no competing financial interests.
Author contributions: M.G., F.A.N., F.P., M.R., and T.M. designed research; M.G. performed research; M.G. analyzed data; M.G., F.P., M.R., and T.M. wrote the paper. 


\section{Introduction}

Traumatic brain injury (TBI) leads to a multifactorial and mostly deleterious secondary inflammatory response in the brain. The degree of injury is related to the severity of the inflammation. Directly after the primary trauma, extravasation of neutrophils, blood-brain barrier damage, astrocyte and microglia activation, migration of leucocytes and phagocytes and cytokine and chemokine production occurs (Morganti-Kossmann et al., 2007). These events create oxidative stress. Reactive oxygen species (ROS) and reactive nitrogen species (RNS) overwhelm the antioxidative response, react with proteins, lipids, carbohydrates and nucleic acids, which results in irreversible cellular damage (Bains and Hall, 2011).

Outcome in TBI varies considerably. The difference of individual responses to trauma is considered a major cause to why experimental head injury findings are difficult to apply to clinical trauma and to why trials in neuroprotection for human TBls have failed (Maas and Menon, 2012). It is possible that individual differences in the antioxidative defense affect the severity of the secondary injury, and it was hypothesized that genetic host factors, such as individual inflammatory responses to traumatic stimuli that were defined for DA and PVG rats (AI Nimer et al., 2013) would be one explanatory factor for heterogeneous outcomes. Unexpectedly, large differences in inflammatory responses did not correlate with discernible differences in posttraumatic neuronal death (Günther et al., 2012). The animals seemed robustly armed to deal with the inflammatory challenge despite inter-strain differences in inducible nitric oxide synthase (iNOS) production, which had been hypothesized to correlate with neuronal death; each animal seemed to respond appropriately on a system level. Recently, immunologic responses have been studied on a system level (Aderem and Smith, 2004; Brodin and Davis, 2017) and a system level explanation would fit the fact that not only the potentially damaging iNOS was upregulated in one strain, but also manganese $\mathrm{O}_{2}^{-}$dismutase (MnSOD), that would protect by decreasing substrates for peroxynitrite $\left(\mathrm{ONOO}^{-}\right)$formation. Genetic polymorphisms influence the inflammatory activity in the central nervous system (Jordan, 2007; McAllister, 2010; Dardiotis et al., 2010), but it is unknown to what extent this affects oxidative stress in traumatic injury. Transgenic animals have been manipulated to study the impact of single genes on oxidative stress (Misawa et al., 2006; Holley et al., 2011); mutations

This work was supported by the Swedish Defense and ALF Stockholms Läns Landsting.

Acknowledgements: This work is dedicated to Dr. Stefan Plantman, an excellent neuroscientist and dedicated teacher, who sadly passed away on January 12, 2017 at the age of 42 years, in Stockholm, Sweden, during the completion of the article.

Correspondence should be addressed to Mattias Günther, Department of Neuroscience, Section of Experimental Traumatology, Karolinska Institutet, Retzius Väg 8, B1:5, SE-171 77 Stockholm, Sweden, E-mail: mattias.gunther@ki.se. DOI:http://dx.doi.org/10.1523/ENEURO.0335-17.2018

Copyright (C) 2018 Günther et al.

This is an open-access article distributed under the terms of the Creative Commons Attribution 4.0 International license, which permits unrestricted use, distribution and reproduction in any medium provided that the original work is properly attributed. that affected MnSOD were either lethal or seemed to correlate with adaptive reactions. The genetic similarity in inbred animals is due to preserved spontaneous mutations, which is why inbred animals comprise a biological system rather than a single genetic abnormality. Inbred animals offer models to study differences in inflammatory responses between genetically similar groups of animals on a system level and are in that aspect more similar to the clinical situation. A patient represents a biological system with its unique and spontaneous genetic makeup. We therefore compared the neuronal antioxidative response in inbred rat strains dark agouti (DA) and piebald viral glaxo (PVG). DA has high susceptibility to, and PVG is protected from CNS inflammation connected to TBI, experimental autoimmune encephalomyelitis, nerve axotomy and spinal cord injury (Reid et al., 2010; Al Nimer et al., 2011). DA responds with increased levels of macrophages, granulocytes, NK-cells, microglia and complement factors C3, C1q, and CD11b compared to PVG after TBI (Bellander et al., 2010; Günther et al., 2012; Al Nimer et al., 2013). Inflammatory cells induce ROS in the CNS (Block et al., 2007). C1q-/- mice neurons had lower oxidative stress after hypoxia/ischemia (Ten et al., 2010). C3-/- mice had better outcome after brain ischemia (Mocco et al., 2006). We hypothesized that the phenotypes of DA and PVG would differ in the regulation of the antioxidative response, oxidative stress levels and ultimately cell survival. The aim was to determine whether these genetically unique strains would respond according to individual patterns when subjected to oxidative challenges in vitro and whether such patterns could be determined and described. The cell culture environment is void of inflammatory cells and circulating cytokines which allows for the identification of an inherent neural antioxidative response.

Primary neuronal cell cultures were exposed to key oxidants in TBI; $\mathrm{NO}$, superoxide $\left(\mathrm{O}_{2}^{-}\right)$, and $\mathrm{ONOO}^{-}$(Bains and Hall, 2011; Fig. 1). NO reacts with $\mathrm{O}_{2}^{-}$to form ONOO (Faraci, 2006; Lambert and Brand, 2009). ONOO- causes protein nitration, lipid peroxidation, DNA damage and inhibition of mitochondrial electron transport, leading to necrotic cell death (Lu et al., 2009). Isolated neurons were selected due to their particular vulnerability to oxidative stress. Postmitotic neurons cannot divide to replace or dilute damaged components, and have low levels of antioxidants compared to glia (Almeida et al., 2002).

Antioxidative enzymes MnSOD and peroxiredoxin 5 (PRDX5) were compared and correlated to markers of lipid peroxidation; 4-hydroxynonenal (4-HNE), protein nitration; 3-nitrotyrosine (3-NT) and neuronal death detected by lactate dehydrogenase (LDH) release. In addition, neuronal iNOS induction was investigated together with direct oxidative effects of $4-\mathrm{HNE}$.

\section{Materials and Methods}

\section{Primary neuronal cultures}

All animal procedures were performed in accordance with the Karolinska Institutet Animal Care Committee's regulations. The DA strain was originally obtained from Medizinische Hochschule, Hannover, Germany while the 


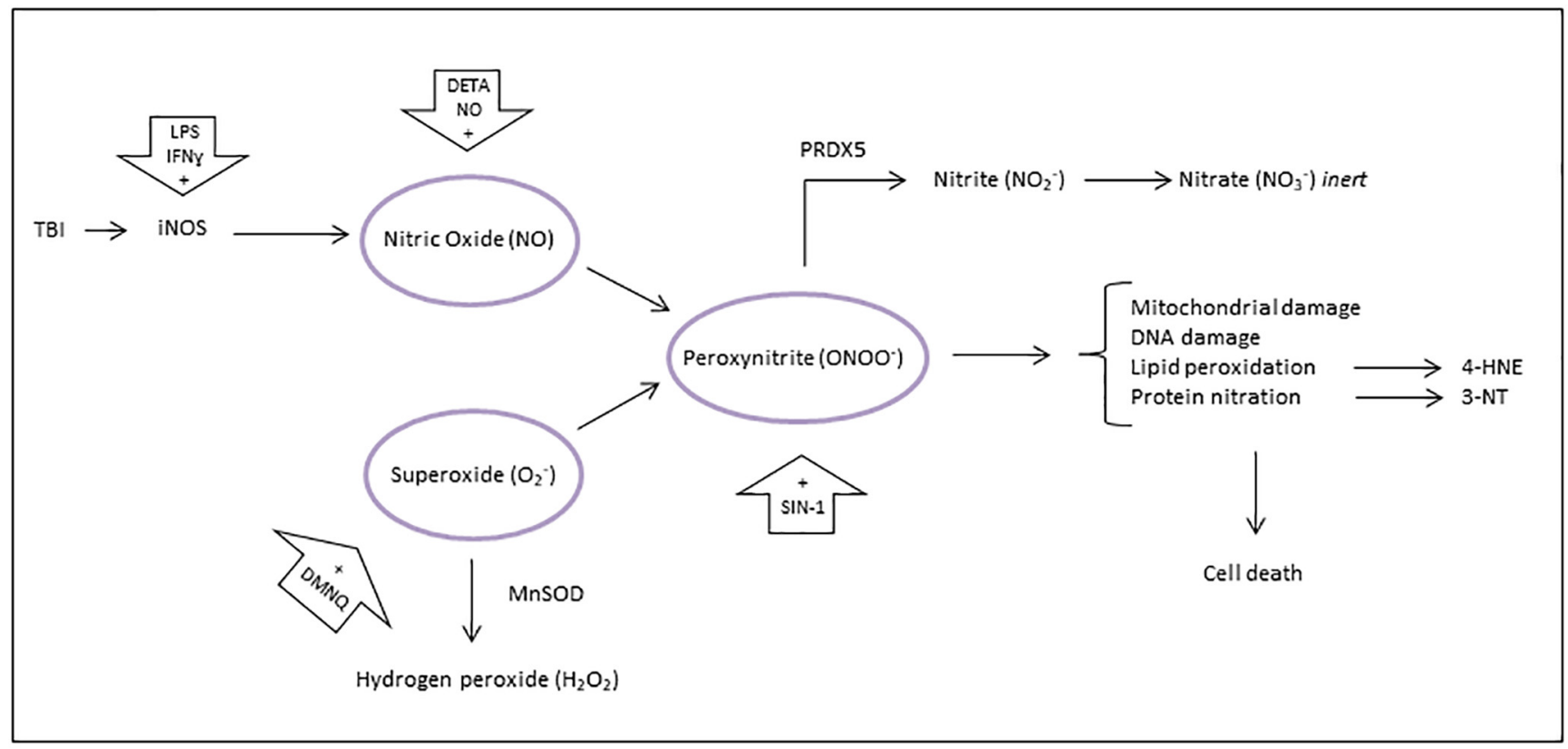

Figure 1. Primary neuronal cell cultures were exposed to key oxidants in $\mathrm{TBI}$ : $\mathrm{ONOO}^{-}, \mathrm{NO}$, and $\mathrm{O}_{2}^{-}$. $\mathrm{NO}$ reacts with $\mathrm{O}_{2}^{-}$to form $\mathrm{ONOO}^{-}$. $\mathrm{ONOO}^{-}$causes protein nitration, lipid peroxidation, DNA damage, and inhibition of mitochondrial electron transport, leading to necrotic cell death. $\mathrm{O}_{2}^{-}$is removed by MnSOD and $\mathrm{ONOO}^{-}$is removed by PRDX5.

PVG.AV1 strain was obtained from Harlan UK Ltd. All animals were bred in an in-house breeding facility with 12/12 h light/dark cycles and fed standard rodent chow and water ad libitum. Four female DA and PVG rats were simultaneously pared with respective males for $72 \mathrm{~h}$. Pregnant rats were asphyxiated by $\mathrm{CO}_{2} 18$ days later, ensuring an embryonic post gestation age between E18 and E21. Hippocampal neuronal cultures from DA and PVG were prepared simultaneously by dissecting the embryonic hippocampi before dissociation by trypsin (Life Technologies) in $37^{\circ} \mathrm{C}$ for 15 min followed by mechanical dissociation by a Pasteur pipette. The cell concentration was determined in the suspension by Countess automated cell counter (Life Technologies) and cells were seeded at $3 \times 10^{5}$ cells/well and placed in Nunclon 24- or 48-well plates (Thermo Scientific), coated with poly-Llysine (Sigma-Aldrich). The cells were kept in Neurobasal medium supplemented with $B_{27}, 200 \mathrm{mM}$ L-glutamine, and $15 \mu \mathrm{g} / \mathrm{ml}$ gentamicin (Life Technologies). The $B_{27}$ supplement contained antioxidants vitamin $\mathrm{E}$, vitamin $\mathrm{E}$ acetate, SOD, catalase, and glutathione. The neuronalglial ratio was $>98 \%$ determined by immunofluorescent double staining with NeuN and GFAP (data not shown). No differences were seen in fetus count per pregnancy, fetal size, cell count at seeding and average cell size at seeding, ensuring equal conditions at oxidative provocation (data not shown).

\section{Oxidative stress}

Twenty-four hours after seeding, the medium was changed to Neurobasal medium with $B_{27}$ void of antioxidants. The cells were exposed to oxidative stress for $2-24$ $\mathrm{h}$. For the oxidative stress analysis at $2 \mathrm{~h}$, parallel cultures were prepared with $B_{27}$ containing antioxidants, to determine reversibility. Oxidative stress was produced by the following compounds. (1) Diethylenetriamine/NO adduct (DETA NO) releases $2 \mathrm{M} \mathrm{NO} / \mathrm{mol}$ parent compound (Sigma Aldrich). A stock was prepared $(50 \mathrm{mM})$ in $\mathrm{dH}_{2} \mathrm{O}$, which was diluted in cell culture medium in concentrations according to previous studies (Dranka et al., 2010, 2011). (2) 2,3-Dimethoxy-1,4-naphthoquinone (DMNQ) releases $\mathrm{O}_{2}^{-}$(Sigma Aldrich). A stock was prepared (15 mM) in DMSO, which was diluted in cell culture medium in concentrations according to previous studies (Tamm et al., 2008; Dranka et al., 2010, 2011). The concentration of DMSO in cell culture medium did not exceed $0.1 \%$. (3) 3-Morpholinosydnonimine hydrochloride (SIN-1) uses molecular oxygen to generate both $\mathrm{O}_{2}^{-}$and $\mathrm{NO}$ that spontaneously form $\mathrm{ONOO}^{-}$(Sigma Aldrich). A stock was prepared $(3 \mathrm{mM})$ in $\mathrm{dH}_{2} \mathrm{O}$, which was diluted in cell culture medium to concentrations according to previous studies (Trackey et al., 2001; Acquaviva et al., 2004). (4) 4-HNE is formed by peroxidation of fatty acids (Calbiochem). The stock was supplied at $10 \mathrm{mg} / \mathrm{ml}$ and diluted in cell culture medium to concentrations according to previous studies (Malecki et al., 2000; Dranka et al., 2011). Physiologic cellular concentrations are in the range of 0.1 to $3.0 \mu \mathrm{M}$ but may increase to $10 \mu \mathrm{M}$ to $5 \mathrm{mM}$ by oxidative stress (Dianzani, 2003).

\section{Western blotting}

After $24 \mathrm{~h}$ of oxidative stress, cells were washed with $4^{\circ} \mathrm{C}$ HBSS. RIPA lysis buffer (TBS, $1 \%$ Nonidet P-40, $0.5 \%$ sodium deoxycholate, $0.1 \%$ SDS, $0.004 \%$ sodium azide, PMSF, protease inhibitor cocktail, and sodium orthovanadate) was added for $15 \mathrm{~min}$ at $4^{\circ} \mathrm{C}$ (Santa Cruz Biotechnology). Cells were scraped from the bottom of the wells and placed in plastic tubes (six to eight wells were combined in one sample) and centrifuged for $10 \mathrm{~min}$ at $10,000 \mathrm{rpm}$ at $4^{\circ} \mathrm{C}$. The protein content was determined 
Table 1. List of antibodies and reagents used

\begin{tabular}{|c|c|c|c|c|c|}
\hline Antibody/assay & Specificity & Species & Source & Product number & Dilution \\
\hline MnSOD & SOD2 & $\mathrm{Rb}$ & Abcam & ab13533 & $1: 5000$ \\
\hline PRDX5 & Peroxyredoxin V & $\mathrm{Rb}$ & Abcam & ab180587 & $1: 1000$ \\
\hline 4-HNE & 4 Hydroxynonenal & $\mathrm{Rb}$ & Abcam & $a b 46545$ & $1: 1000$ \\
\hline 3-NT & 3-Nitrotyrosine [39B6] & Mo & Abcam & ab61392 & $1: 500$ \\
\hline iNOS & Inducible NO synthase & $\mathrm{Rb}$ & Abcam & ab15323 & $1: 250$ \\
\hline$\alpha$-Tubulin & Loading control & Mo & Abcam & $a b 7291$ & $1: 10,000$ \\
\hline$\alpha$-Tubulin & Loading control & $\mathrm{Rb}$ & Abcam & ab176560 & $1: 1000$ \\
\hline NeuN & Neuron-specific nuclear protein & Mo & Millipore & MAB377 & $1: 500$ \\
\hline GFAP & Glial fibrillary acidic protein & $\mathrm{Rb}$ & Abcam & ab33922 & $1: 1000$ \\
\hline Alexa Fluor 680 & Secondary $680 \mathrm{~nm}$ & $\mathrm{Go} \alpha \mathrm{Rb}$ & Molecular Probes & A21076 & $1: 15,000$ \\
\hline $800 \mathrm{CW}$ & Secondary $800 \mathrm{~nm}$ & Do $\alpha$ Mo & Li-Cor & $926-32212$ & $1: 15,000$ \\
\hline $800 \mathrm{CW}$ & Secondary $800 \mathrm{~nm}$ & $\mathrm{Go} \alpha \mathrm{Rb}$ & Li-Cor & $926-32211$ & $1: 15,000$ \\
\hline LDH assay & Lactate dehydrogenase release & $\mathrm{N} / \mathrm{A}$ & Abcam & ab102526 & N/A \\
\hline
\end{tabular}

in the supernatant by a protein assay (Bio-Rad). Samples were denaturated $\left(70^{\circ} \mathrm{C}, 10 \mathrm{~min}\right)$ and reduced $(2.5 \%$ $\beta$-mercaptomethanol), and loaded on NuPAGE Novex Bis-Tris 10\% mini gels (Life Technologies) with Odyssey protein molecular weight marker (Li-Cor). Electrophoresis and transfer to PVDF membranes were done in XCell SureLock Mini-Cell, with buffers according to manufacturer's instructions (Life Technologies). Membranes were blocked for $1 \mathrm{~h}$ in Odyssey blocking buffer (Li-Cor) and incubated overnight in $4^{\circ} \mathrm{C}$ with primary antibody and $\alpha$-tubulin loading control diluted in Odyssey blocking buffer. Membranes were washed $4 \times 5$ min in PBS $+0.1 \%$ Tween 20 and incubated in secondary antibodies diluted in Odyssey blocking buffer for $1 \mathrm{~h}$, followed by washing $5 \times 5$ min in PBS $+0.1 \%$ Tween 20 before being scanned by Odyssey infrared imaging system (Li-Cor), allowing two antibodies to be detected simultaneously in 700 and 800 $\mathrm{nm}$. Densiometric quantification and normalization to $\alpha$-tubulin were done in Image Studio v.2.1 (Li-Cor). All membranes contained an identical sample from rat macrophage cell line NR8383, stimulated with 500 ng/ml lipopolysaccharide (LPS) from E-coli 0128:B12 (SigmaAldrich) and $100 \mathrm{ng} / \mathrm{ml}$ recombinant rat interferon gamma (IFN-y) (Millipore) for $24 \mathrm{~h}$. The NR8383 sample expressed all proteins/protein-adducts examined allowing all membranes to be normalized to the sample, removing natural differences in Western blotting processing and staining and allowing for comparisons between the membranes. A total of 77 membranes were quantified and normalized to the NR8383 control. Primary and secondary antibodies are specified in Table 1. Protein-HNE adducts and 3-NT were quantified at 36/42 kDa.

\section{LDH assay}

LDH is an oxidoreductase present in all cell types. LDH is released into cell culture medium relative to the loss of cell membrane integrity, thus a marker of necrotic cell damage. LDH activity in cell culture medium was measured by a colorimetric assay (Abcam). LDH reduces NAD to $\mathrm{NADH}$, which interacts with a specific probe to produce a color $(\lambda \max =450 \mathrm{~nm})$, quantified by Multiskan EX plate reader (Thermo Fisher Scientific). A standard curve was constructed and the LDH activity was measured and calculated according to the manufacturer instructions and found to be $5.81-24.05 \mathrm{nmol} / \mathrm{min} / \mathrm{ml}=\mathrm{mU} / \mathrm{ml}$, which was within the range of the assay $(1-100 \mathrm{mU} / \mathrm{ml})$. The LDH activity in the medium was normalized to the total protein amount in the corresponding wells, quantified for Western blotting as previously described.

\section{Cell-IQ}

Cells were photographed at 0 and $24 \mathrm{~h}$ by Cell-IQ live cell imaging and analysis platform (Chipman Technology), a $10 \times$ phase contrast microscope in an incubator setting.

\section{CellROX oxidative stress detection}

CellROX green reagent is a fluorogenic probe for measuring oxidative stress in live cells. The cell-permeant dye is weakly fluorescent while in a reduced state but exhibits bright green photostable fluorescence on oxidation by ROS and subsequent binding to DNA, with absorption/emission maxima of $\sim 485 / 520 \mathrm{~nm}$ (GFP; Life Technologies). CellROX was added to the wells in a $5 \mu \mathrm{M}$ final concentration after 2 h of oxidative stress. NucBlue reagent, a Hoechst 33342 cell-permeant nuclear counterstain, was added for 15 min (Life Technologies). After $30 \mathrm{~min}$, the cells were washed two times with $4^{\circ} \mathrm{C}$ HBSS. The cell culture plates were photographed in $20 \times$ magnification in a Zeiss Observer Z-inverted microscope. For each view, a DAPI and a GFP picture were quantified in CellProfiler (Jones et al., 2008) by measuring the integrated intensity of the GFP staining at the loci of corresponding DAPI staining, thus measuring oxidative stress level per cell.

\section{Statistical analyses}

Statistical analyses were done by GraphPad Prism version 6.05 for Windows (GraphPad Software). All results were related to the baseline of that particular assay, probe and strain, and presented as percentage of the baseline, allowing for comparisons between experiments; $\alpha$-level $p<0.05$ was considered significant. All error bars represent the standard error of the mean. CellROX, Western blottings, and LDH assays were analyzed by two-way ANOVAs with Šídák's multiple comparisons test. Baselines were analyzed by the nonparametric Mann-Whitney test. 

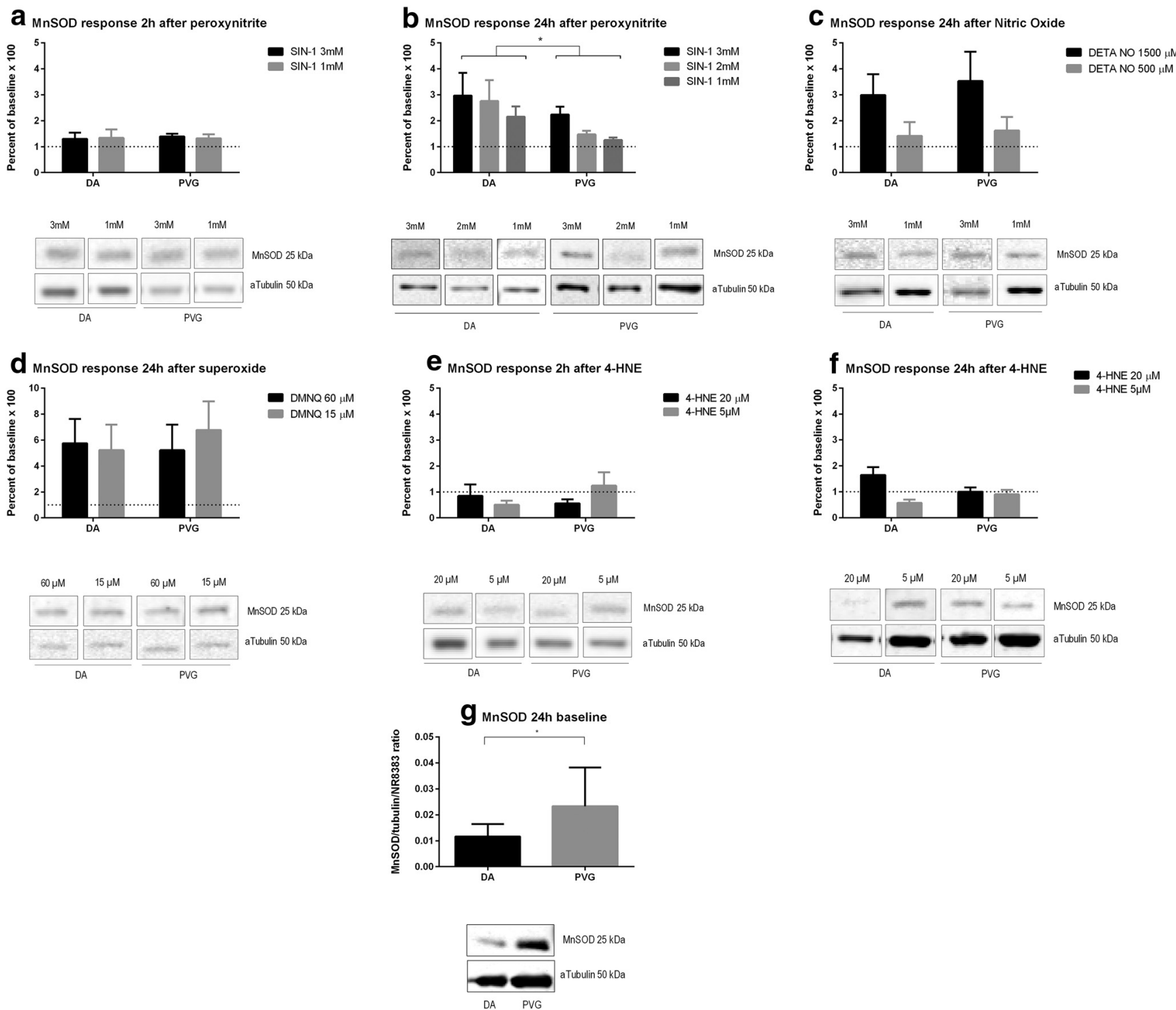

Figure 2. Genetic background regulated antioxidative enzyme MnSOD after oxidative stress. $\mathrm{ONOO}^{-} \mathrm{caused}^{-}$higher $\mathrm{MnSOD}$ synthesis in DA compared to PVG. Baseline levels were higher in PVG compared to DA. No increase was seen at $2 \mathrm{~h}$, confirming a de novo protein synthesis. Dotted lines mark baselines. Pictures are constructed from different parts of gels and marked as such. Densiometric quantification was made as a mean of three consecutive gels which were normalized to both $\alpha$-tubulin and a specific control identical for all gels; $* p<0.05$.

\section{Results}

\section{MnSOD}

$\mathrm{ONOO}^{-}$did not induce MnSOD compared to controls at $2 \mathrm{~h}$ (Fig. 2A). At $24 \mathrm{~h}, \mathrm{MnSOD}$ was induced in DA compared to PVG ( $p<0.05$; Fig. $2 B$ ). NO induced MnSOD at $24 \mathrm{~h}$ equally in DA and PVG (Fig. 2C). $\mathrm{O}_{2}^{-}$induced MnSOD at $24 \mathrm{~h}$ equally in DA and PVG (Fig. 2D). 4-HNE did not induce MnSOD compared to controls at 2 or $24 \mathrm{~h}$ (Fig. 2E,F). Baseline MnSOD levels were higher in PVG compared to DA ( $p<0.05$; Fig. $2 G$ ).

\section{PRDX5}

$\mathrm{ONOO}^{-}$reduced $\mathrm{PRDX} 5$ at $2 \mathrm{~h}$ (Fig. $3 A$ ) and further at $24 \mathrm{~h}$ (Fig. 3B), equally in DA and PVG. NO induced PRDX5 at $24 \mathrm{~h}$ equally in DA and PVG (Fig. $3 C$ ). $\mathrm{O}_{2}^{-}$induced
PRDX5 only at $60 \mu \mathrm{M}$ at $24 \mathrm{~h}$, equally in DA and PVG (Fig. 3D). 4-HNE did not induce PRDX5 in either DA or PVG at $2 \mathrm{~h}$ (Fig. 3E) or $24 \mathrm{~h}$ (Fig. 3F). Baseline PRDX5 expression did not differ between DA and PVG (Fig. 3G).

\section{4-HNE}

$\mathrm{ONOO}^{-}$increased $4-\mathrm{HNE}$ at $2 \mathrm{~h}$, with a higher increase in DA compared to PVG at $1 \mathrm{mM}(p<0.05$; Fig. $4 A)$. At 24 h, 4-HNE formation was instead significantly increased in PVG compared to DA at $2 \mathrm{mM}(p<0.01)$ and $3 \mathrm{mM}$ $(p<0.01$; Fig. 4B). NO increased $4-\mathrm{HNE}$ at $24 \mathrm{~h}$ in PVG compared to DA $\left(p<0.05\right.$; Fig. $4 C$ ). $\mathrm{O}_{2}^{-}$increased $4-\mathrm{HNE}$ at $24 \mathrm{~h}$ in PVG compared to DA $(p<0.05$; Fig. $4 D$ ). Baseline 4-HNE did not differ between DA and PVG Fig. 4E). 

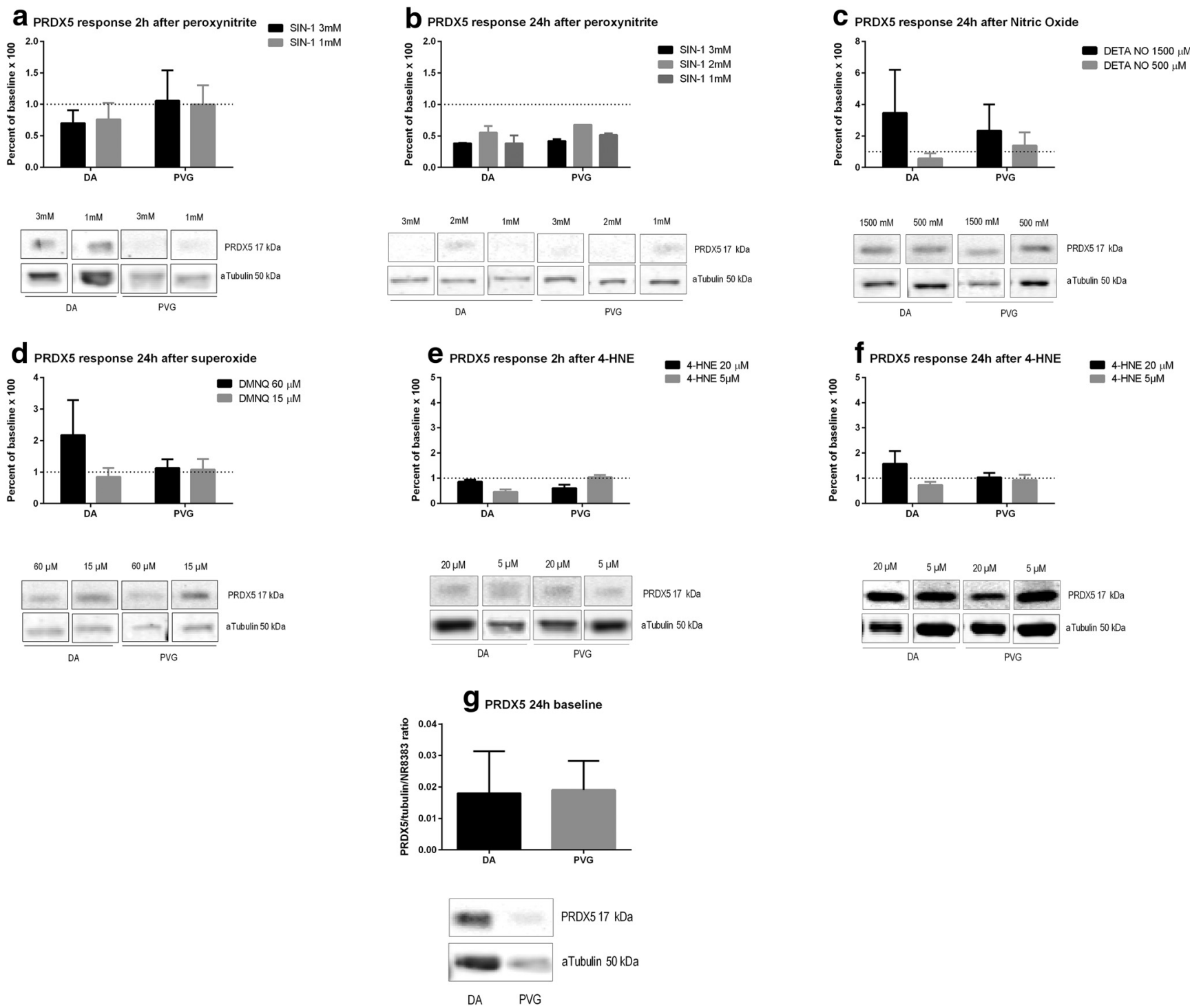

Figure 3. Genetic background did not regulate antioxidative enzyme PRDX5 after oxidative stress. PRDX5 was decreased by ONOO ${ }^{-}$, increased by $\mathrm{NO}$ and $\mathrm{O}_{2}^{-}$, and unchanged by 4-HNE. Baseline expression did not differ between strains. Dotted lines mark baselines. Pictures are constructed from different parts of gels and marked as such. Densiometric quantification was made as a mean of three consecutive gels, which were normalized to both $\alpha$-tubulin and a specific control identical for all gels.

\section{3-NT}

$\mathrm{ONOO}^{-}$increased 3-NT at $2 \mathrm{~h}$ equally in DA and PVG (Fig. 5A), and at $24 \mathrm{~h}, 3-\mathrm{NT}$ increased in PVG compared to $\mathrm{DA}$ at $3 \mathrm{mM}(p<0.05$; Fig. $5 B)$. NO increased $3-\mathrm{NT}$ at 24 $\mathrm{h}$ higher in PVG compared to DA at $1500 \mu \mathrm{M}(p<0.05$; Fig. $5 \mathrm{C}$ ). $\mathrm{O}_{2}^{-}$increased nitrotyrosine at $24 \mathrm{~h}$ equally in DA and PVG (Fig. 5D). 4-HNE did not increase 3-NT in either DA or PVG at 2 or $24 \mathrm{~h}$ (Fig. 5E,F). Baseline nitrotyrosine did not differ between DA and PVG (Fig. 5G).

\section{Acute neuronal oxidative stress detected by CellROX}

$\mathrm{ONOO}^{-}$resulted in dose dependent oxidative stress at $2 \mathrm{~h}$, with higher levels in DA compared to PVG at $3 \mathrm{mM}(p$ $<0.05$; Fig. 6A). This effect was fully reversed by the addition of antioxidants. NO resulted in oxidative stress at $2 \mathrm{~h}$, with higher levels in DA compared to PVG at $1500 \mu \mathrm{M}$ $(p<0.05)$ and $500 \mu \mathrm{M}(p<0.05$; Fig. 6B). This effect was fully reversed by the addition of antioxidants. $\mathrm{O}_{2}^{-}$resulted in oxidative stress at $2 \mathrm{~h}$, with higher levels in DA compared to PVG at $15 \mu \mathrm{M}(p<0.05)$ and $60 \mu \mathrm{M}(p<0.05$; Fig. $6 C$ ). This effect was fully reversed by the addition of antioxidants. 4-HNE did not cause oxidative stress at $2 \mathrm{~h}$ in either DA or PVG (Fig. 6D).

\section{Cell death detected by LDH release}

$\mathrm{ONOO}^{-}$caused increased cell death in PVG compared to $\mathrm{DA}$ at $1 \mathrm{mM}(p<0.005$; Fig. $7 A)$. NO caused increased cell death in PVG compared to DA at $500 \mu \mathrm{M}(p<0.01$; Fig. 7B). $\mathrm{O}_{2}^{-}$caused increased cell death in PVG compared to DA at $15 \mu \mathrm{M}(p<0.001)$ and $60 \mu \mathrm{M}(p<0.001$; Fig. 7C). 4-HNE caused equal levels of cell death in DA and PVG (Fig. 7D). Baselines of LDH were equal between DA and PVG (Fig. 7E). 

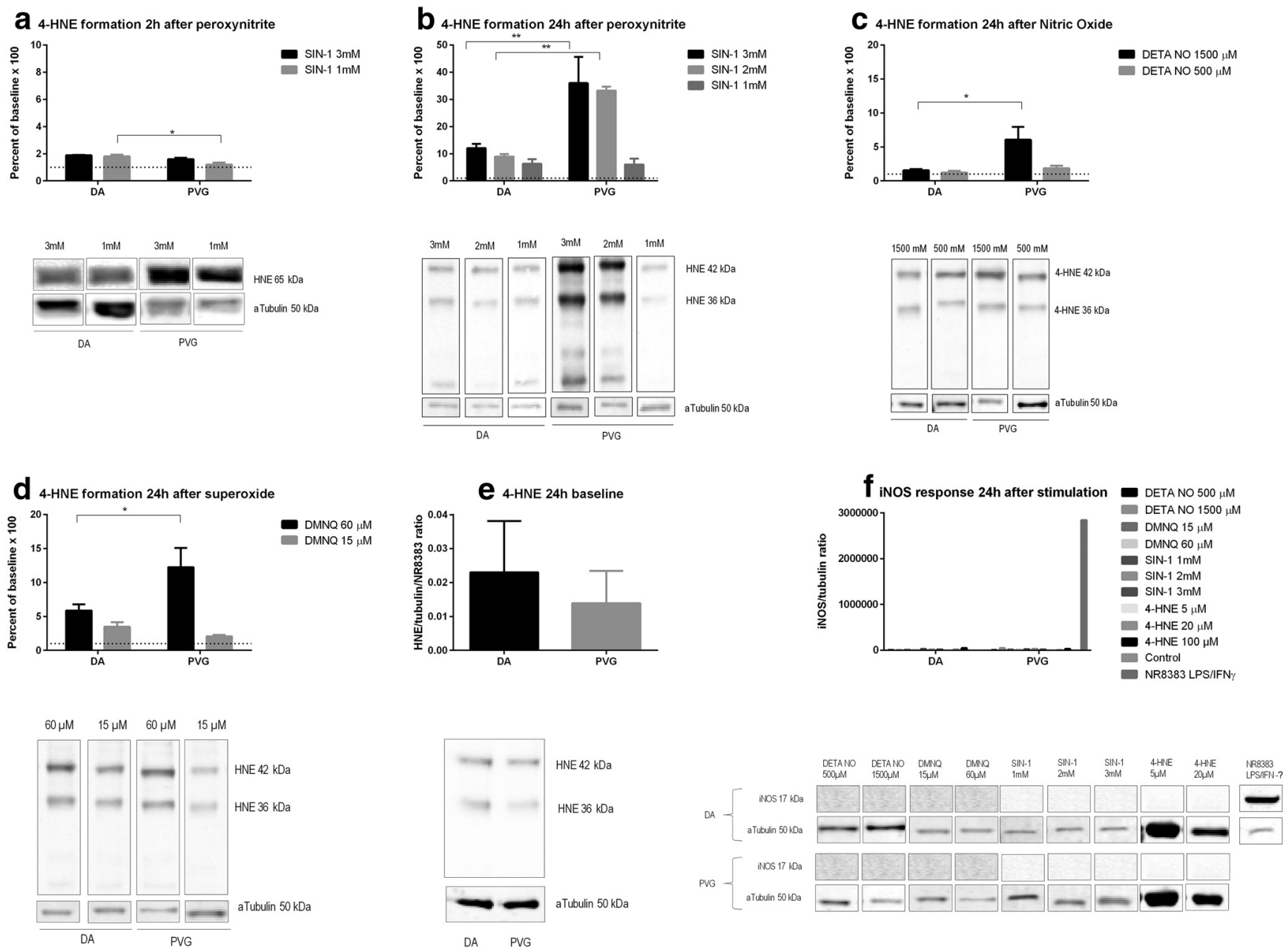

Figure 4. Genetic background effected 4-HNE formation after oxidative stress. PVG had higher levels of 4-HNE after oxidative stress by $\mathrm{ONOO}^{-}$, NO, and $\mathrm{O}_{2}^{-}$compared to DA at $24 \mathrm{~h}$. A discrete increase was seen at $2 \mathrm{~h}$. ONOO ${ }^{-}$caused a $35 \times$ increase of $4-\mathrm{HNE}$ in PVG, compared to $7 \times$ by $\mathrm{NO}$ and $12 \times$ by $\mathrm{O}_{2}^{-}$, why $\mathrm{ONOO}^{-}$was confirmed as the most powerful oxidant. Baseline levels did not differ between strains. Neuronal iNOS was not induced by any of the oxidants $\mathrm{ONOO}^{-}, \mathrm{NO}^{-} \mathrm{O}_{2}^{-}$, or $4-\mathrm{HNE}$. Dotted lines mark baselines. Pictures are constructed from different parts of gels and marked as such. Densiometric quantification was made as a mean of three consecutive gels which were normalized to both $\alpha$-tubulin and a specific control identical for all gels; $* p<0.05$ and $* * p<$ 0.01 .

\section{iNOS}

iNOS was not induced by any of the oxidants $\mathrm{ONOO}^{-}$, $\mathrm{NO}, \mathrm{O}_{2}^{-}$, or 4-HNE (Fig. 4F).

\section{Cell-IQ}

Morphologic changes in the neurospheres were detected consistently after $\mathrm{ONOO}^{-}, \mathrm{NO}, \mathrm{O}_{2}^{-}$, and 4-HNE provocation at $24 \mathrm{~h}$. Baseline cultures did not exhibit signs of cell death. Cell death was extensive after $\mathrm{ONOO}^{-}$compared to $\mathrm{NO}$, $\mathrm{O}_{2}^{-}$, and 4-HNE. Differences in cell death based on morphology between DA and PVG could not be established. Morphologic signs of cell death were reversed in the 4-HNE groups by the addition of antioxidants (Fig. 8).

\section{Discussion}

The findings of this study suggest genetically encoded biologically relevant differences in the response of the neuron to oxidative stress (Fig. 9). Neurons from DA and PVG rats appeared to represent two different response patterns to oxidative challenges. Each mode entailed a robust and balanced reaction which may minimize cellular injury and could be viewed as system on a cellular level. In particular, variability in the regulation of MnSOD may explain some of the strain differences, where MnSOD was increased to a greater extent in DA neurons, likely due to a de novo protein synthesis since no increase was detected early. MnSOD converts $\mathrm{O}_{2}^{-}$to hydrogen peroxide $\left(\mathrm{H}_{2} \mathrm{O}_{2}\right)$ in mitochondria which limits oxidative stress in TBI (Flynn and Melov, 2013). $\mathrm{O}_{2}^{-}$caused a $6 \times \mathrm{MnSOD}$ induction compared to $3 \times$ by $\mathrm{NO}$ and $1.5 \times$ by $\mathrm{ONOO}^{-}$, confirming $\mathrm{O}_{2}^{-}$as a main trigger for MnSOD induction. The phenotype difference was observed specifically by $\mathrm{ONOO}^{-}$ but not $\mathrm{O}_{2}^{-}$or NO. It is possible that greater initial oxidative stress was required for effective MnSOD induction in DA. This notion is supported by the fact that $\mathrm{ONOO}^{-}$caused the highest oxidative stress levels $(10 \times)$ compared to NO $(2 \times)$ and $\mathrm{O}_{2}^{-}(3 \times)$, and extensive morphologic signs of 
A 3-Nitrotyrosine formation $2 \mathrm{~h}$ after peroxynitrite
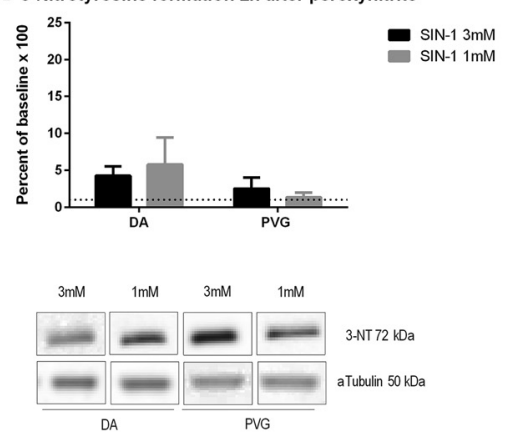

d 3-Nitrotyrosine formation $24 \mathrm{~h}$ after superoxide
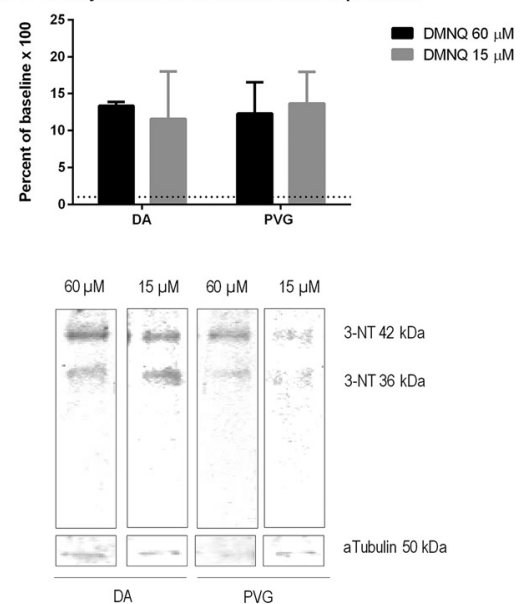

b 3-Nitrotyrosine formation 24h after peroxynitrite
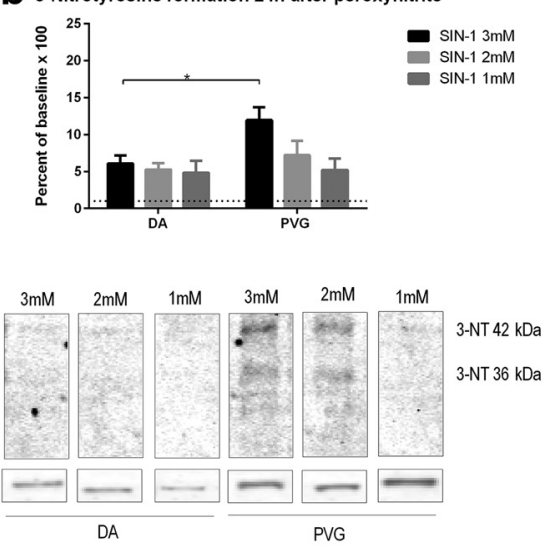

C 3-Nitrotyrosine formation $2 \mathrm{~h}$ after 4-HNE

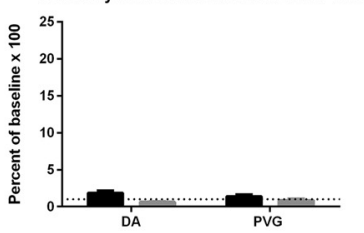

4-HNE $20 \mu \mathrm{M}$
4-HNE 5 $\mu \mathrm{M}$
C 3-Nitrotyrosine formation 24h after Nitric Oxide

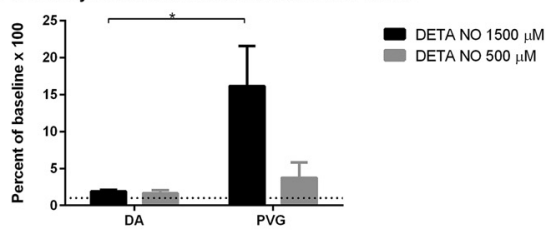

$1500 \mathrm{mM} 500 \mathrm{mM} \quad 1500 \mathrm{mM} \quad 500 \mathrm{mM}$

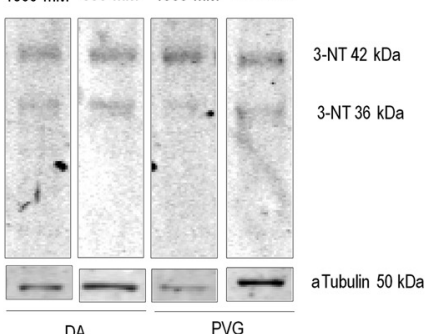

DA
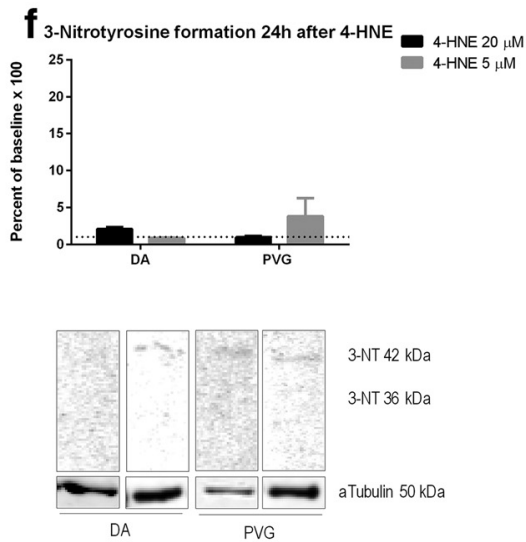
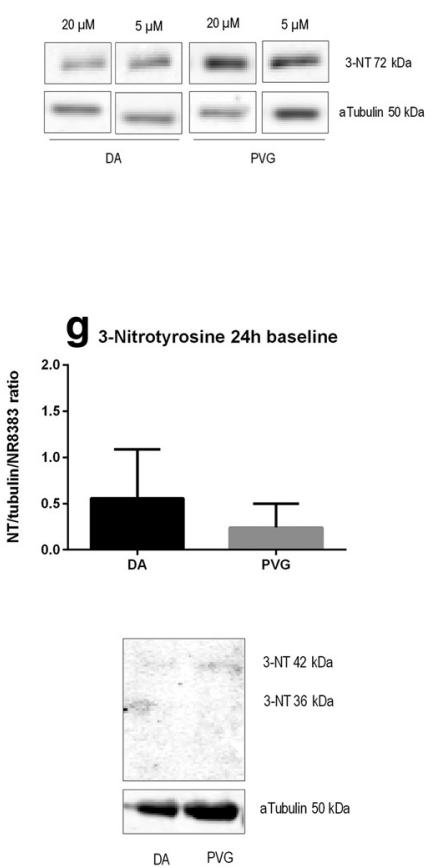

Figure 5. Genetic background effected 3-NT formation after oxidative stress. PVG had higher levels of 3-NT after oxidative stress by $\mathrm{ONOO}^{-}$and $\mathrm{NO}$. $\mathrm{ONOO}^{-}, \mathrm{NO}$, and $\mathrm{O}_{2}^{-}$consistently caused a $10-15 \times$ increase of 3-NT, why nitrosylation occurred indiscriminate of oxidant. A discrete increase was seen at $2 \mathrm{~h}$. Baseline levels did not differ between strains. Dotted lines mark baselines. Pictures are constructed from different parts of gels and marked as such. Densiometric quantification was made as a mean of three consecutive gels which were normalized to both $\alpha$-tubulin and a specific control identical for all gels; $* p<0.05$.

cell death in Cell-IQ. Interestingly, our findings are to some degree unexpected, since the DA strain has been associated with a higher degree of inflammation and oxidative damage in in vivo models for nerve trauma (Piehl et al., 1999; Lundberg et al., 2001). It can therefore be speculated if the pro-inflammatory phenotype of DA has led to higher resilience to oxidative stress in nerve cells, thus an example of hormesis. In other models both repeated oxidative stress by $\mathrm{H}_{2} \mathrm{O}_{2}$ and ischemic precondition led to adaptive and increased protective mechanisms 
A Oxidative stress $2 \mathrm{~h}$ after peroxynitrite
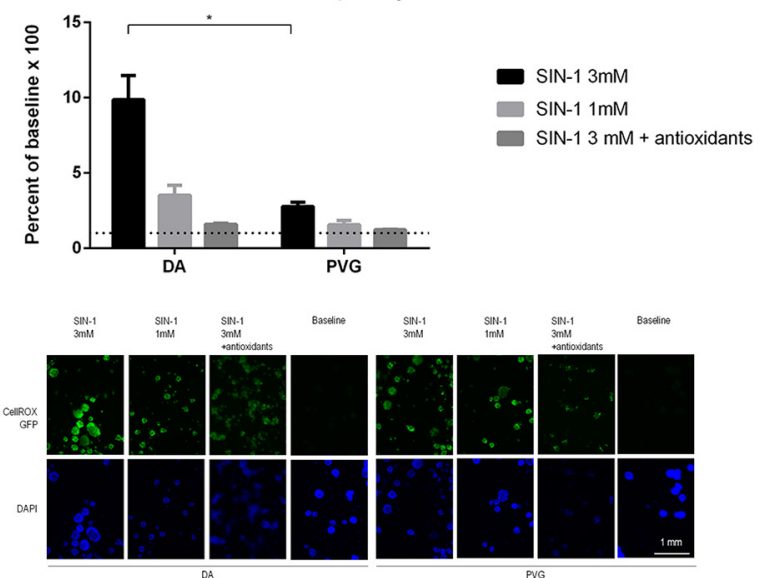

C Oxidative stress $2 \mathrm{~h}$ after superoxide

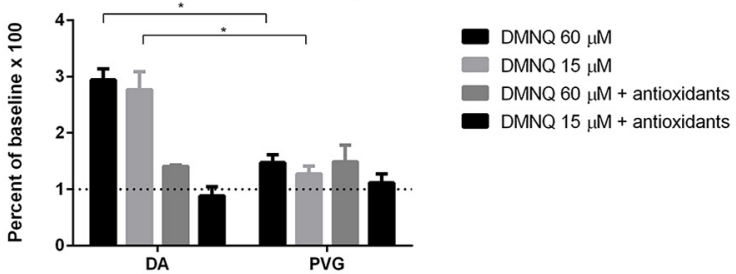

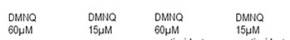
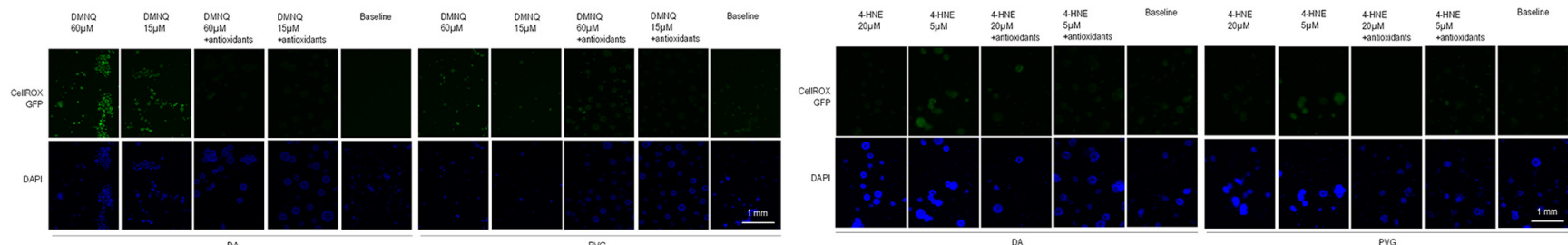

Figure 6. Genetic background effected the acute oxidative stress at 2 h. Oxidative stress levels measured by CellROX fluorescent marker were consistently higher in $\mathrm{DA}$ after $\mathrm{NO}, \mathrm{O}_{2}^{-}$, and $\mathrm{ONOO}^{-}$, compared to PVG. ONOO ${ }^{-}$caused a $10 \times$ increase of oxidative stress compared to a $2 \times$ increase for $\mathrm{NO}$ and $3 \times$ for $\mathrm{O}_{2}^{-}$why $\mathrm{ONOO}^{-}$was confirmed as the most powerful oxidant. 4-HNE did not cause oxidative stress in the neurons. Dotted lines mark baselines; $* p<0.05$.
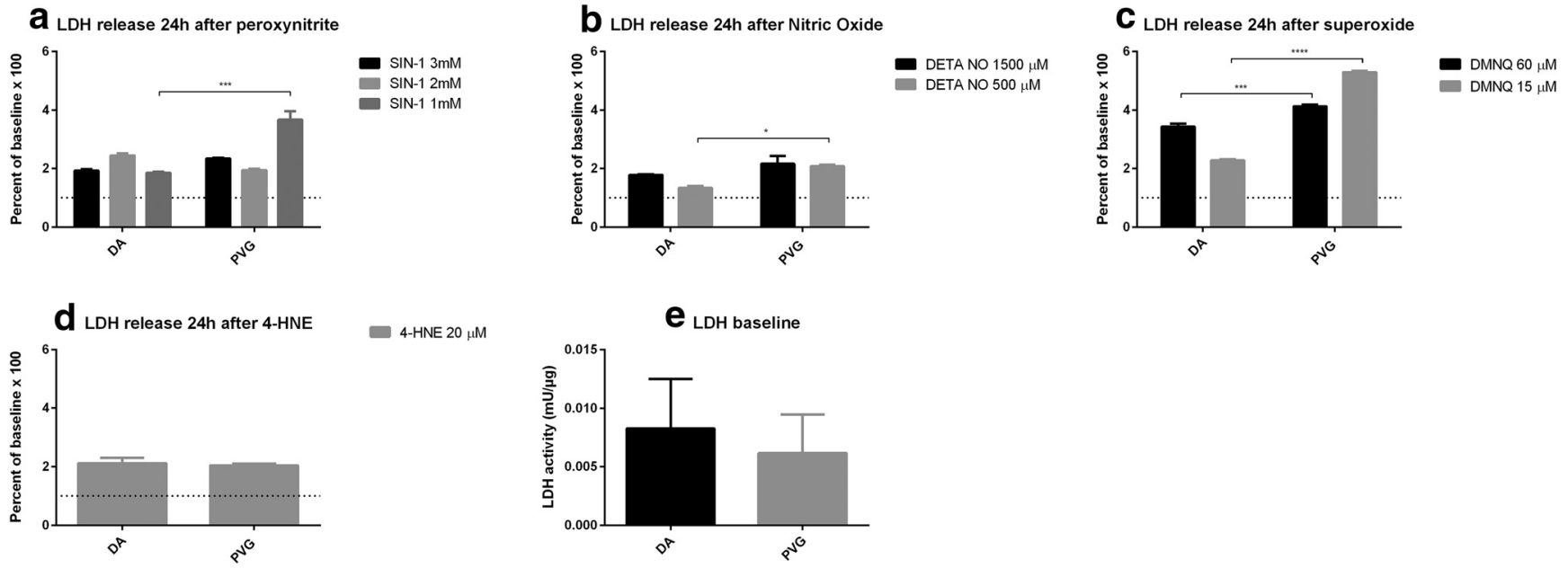

Figure 7. Genetic background effected neuronal death, measured by LDH, after oxidative stress. PVG had increased neuronal death after oxidative stress consistently by $\mathrm{ONOO}^{-}$, $\mathrm{NO}$, and $\mathrm{O}_{2}^{-}$compared to DA at $24 \mathrm{~h}$. Baseline levels did not differ between strains. Dotted lines mark baselines; $* p<0.05$, $* * * p<0.005$, and $* * * * p<0.001$. 
DA

PVG

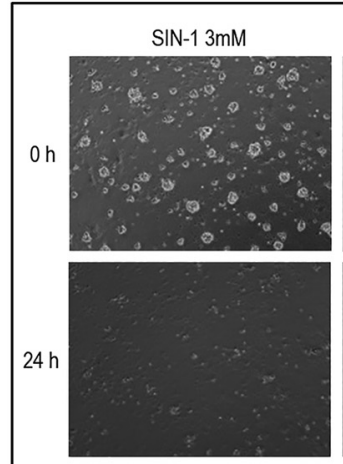

DMNQ 60 $\mu \mathrm{M}$

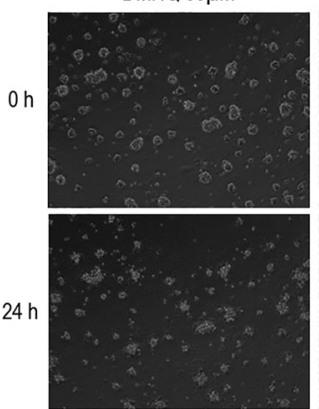

Deta NO 1500 $\mu \mathrm{M}$
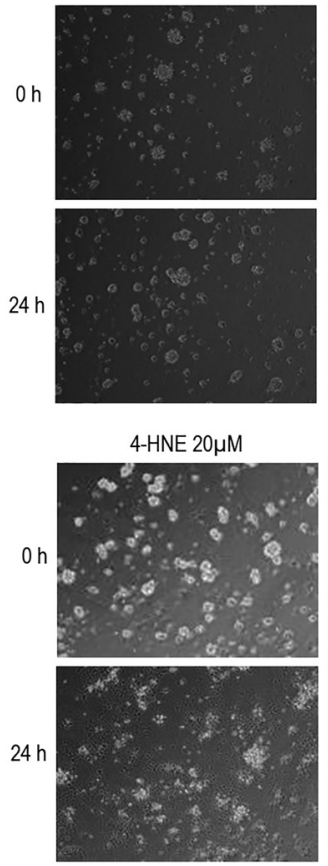

$\mathrm{SIN}-11 \mathrm{mM}$

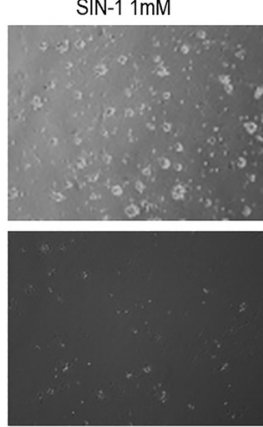

DMNQ $15 \mu \mathrm{M}$

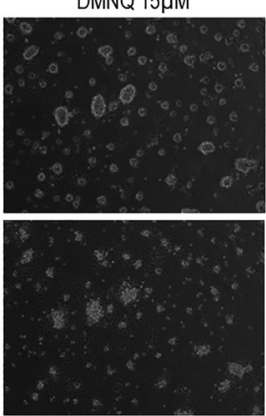

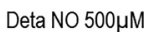
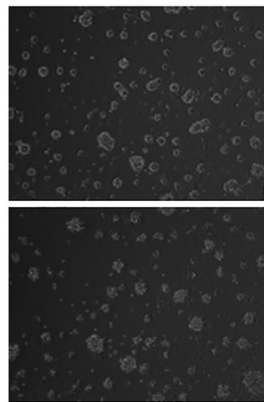

4-HNE $20 \mu \mathrm{M}$ +antioxidants

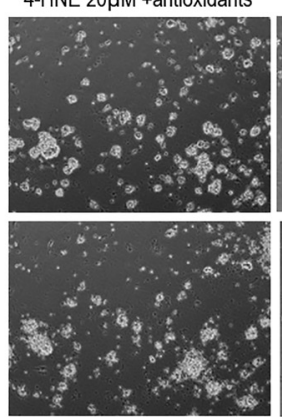

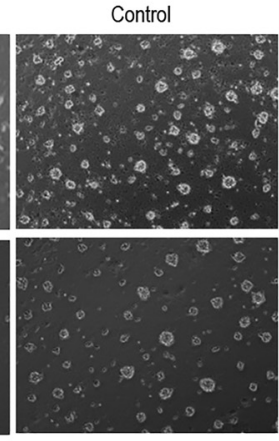

Control

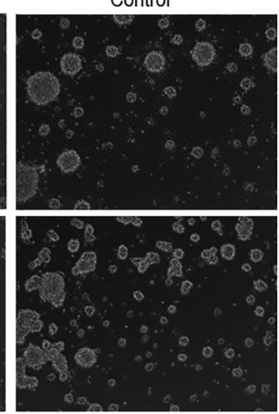

Control
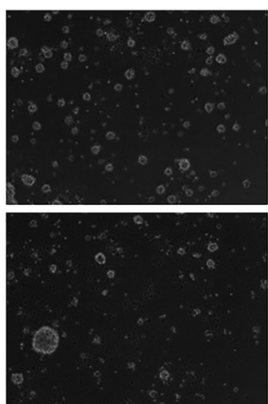

Control
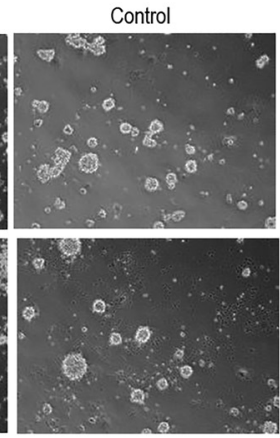

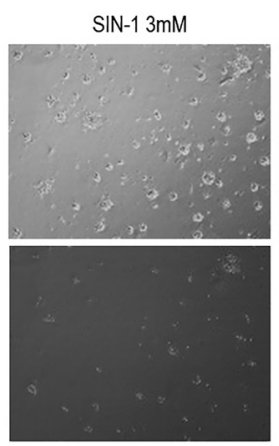

DMNQ 60 $\mu \mathrm{M}$

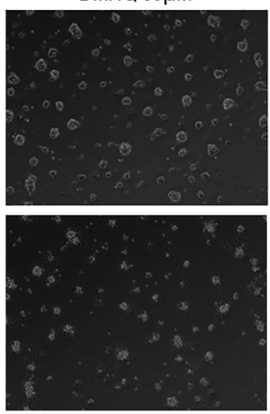

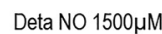
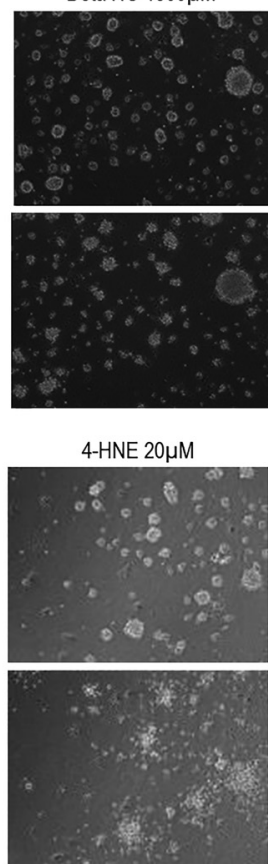

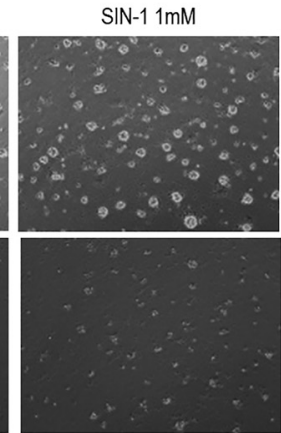

DMNQ $15 \mu \mathrm{M}$

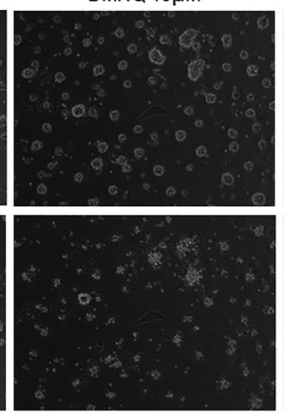

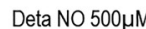

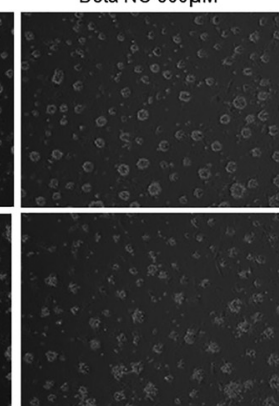

4-HNE $20 \mu \mathrm{M}$ +antioxidants

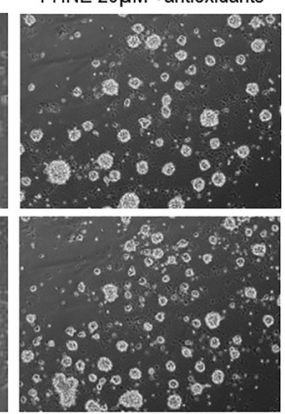

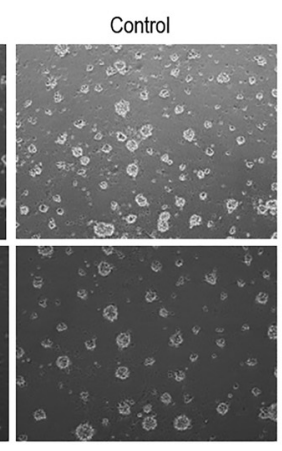

Control

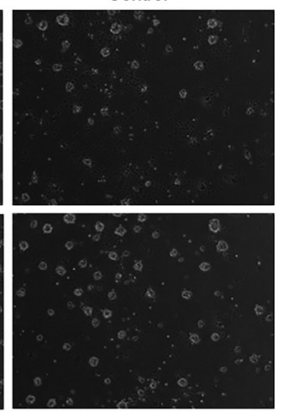

Control
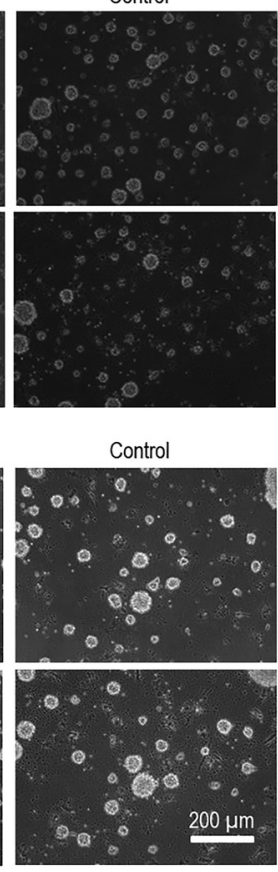

Figure 8. Photomicrographs by Cell-IQ of neuronal cell cultures. Morphologic changes were detected after $\mathrm{ONOO}^{-}(\mathrm{SIN}-1)$, NO (DETA NO), $\mathrm{O}_{2}^{-}$(DMNQ), and 4-HNE. Control cultures did not exhibit signs of cell death. Cell death was extensive after ONOO compared to $\mathrm{NO}, \mathrm{O}_{2}^{-}$, and 4-HNE. Morphologic signs of cell death were reversed in the 4-HNE groups by the addition of antioxidants.

in cell cultures (Pickering et al., 2013; Kalogeris et al., 2014). Further studies are needed to clarify the impact of long-term genetic adaptation to oxidative stress and the mechanisms thereof. In contrast, PRDX5 induction was equal in DA and PVG, consistently for all oxidants. PRDX5 is a selective $\mathrm{ONOO}^{-}$reductase which protects from oxidative stress in TBI (Szabó et al., 2007). $\mathrm{NO}$ and $\mathrm{O}_{2}^{-}$ caused increased PRDX5 synthesis and $\mathrm{ONOO}^{-}$caused 


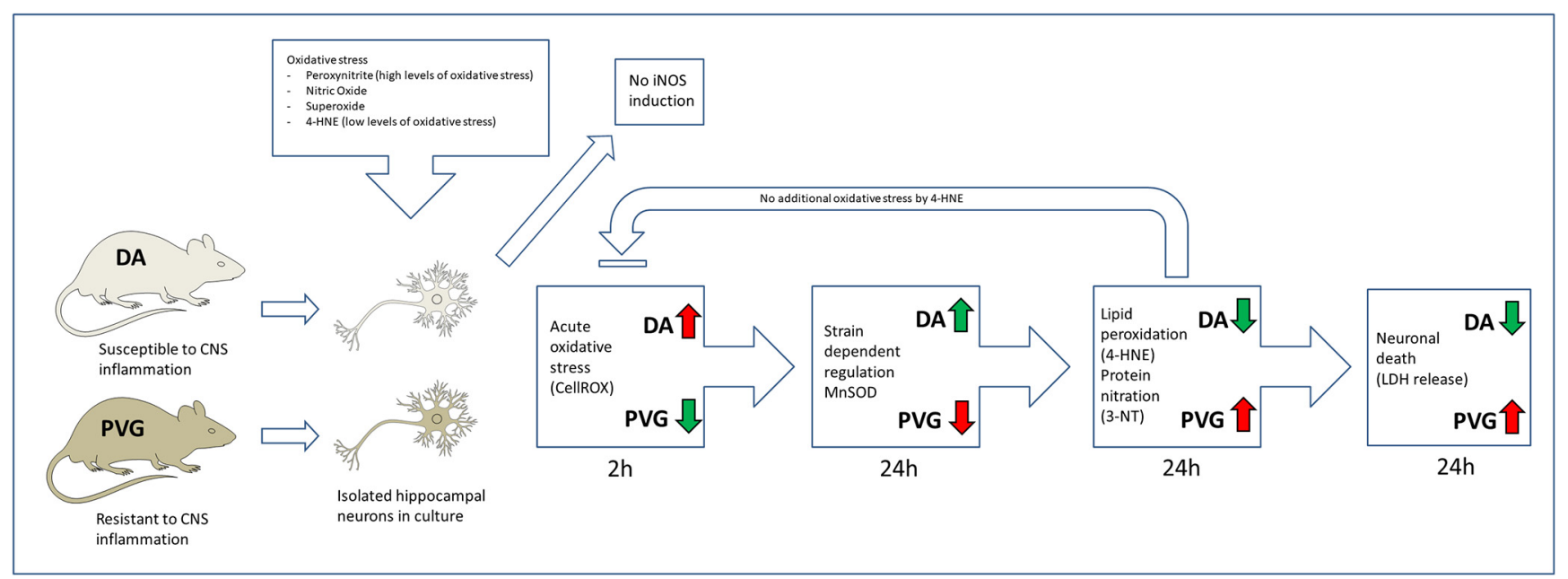

Figure 9. Graphic presentation of the phenotype regulated neuronal antioxidative response.

depletion. The phenotype regulated antioxidative response was therefore not a result of a general increase of antioxidative systems, but specific for MnSOD. Lipid peroxidation marker 4-HNE was consistently decreased in DA compared to PVG after $\mathrm{NO}, \mathrm{O}_{2}^{-}$, and $\mathrm{ONOO}^{-}$. 4-HNE is an $\alpha, \beta$-unsaturated aldehyde generated by peroxidation of $\omega-6$ polyunsaturated fatty acids. The initial oxidative stress and subsequent lipid peroxidation correlated, since $\mathrm{ONOO}^{-}$resulted in a $35 \times$ increase of $4-\mathrm{HNE}$ in PVG, compared to $7 \times$ by $\mathrm{NO}$ and $12 \times$ by $\mathrm{O}_{2}^{-}$. It may be that higher MnSOD levels in DA provided a higher degree of protection from lipid peroxidation. At physiologic concentrations, 4-HNE acts as an endogenous signaling molecule but causes neuronal death in high concentrations (Kruman and Mattson, 1999; Uchida, 2003). It is possible that neurons respond specifically to pathologic 4-HNE concentrations by increasing antioxidative enzymes similarly to the response to $\mathrm{NO}, \mathrm{O}_{2}^{-}$, and peroxyntrite. 4-HNE induces peroxyredoxins in macrophages (Ishii et al., 2004). Direct exposure of the neurons to exogenous 4-HNE was therefore investigated, which failed to induce MnSOD or PRDX5 in either strain. No oxidative stress was detected at $2 \mathrm{~h}$, and protein nitration marker 3-NT was not elevated. The neurons seemed relatively resistant and unresponsive to toxic effects by $4-\mathrm{HNE}$. Cell death measured by $\mathrm{LDH}$ release was half compared to $\mathrm{NO}, \mathrm{O}_{2}^{-}$, and $\mathrm{ONOO}^{-}$and no morphologic signs of cell death were detected. It is probable that toxicity associated with 4-HNE in the whole brain is an effect of the general oxidative stress environment. Neurons may therefore lack specific endogenous defense systems to 4-HNE and be dependent on an antioxidative response by surrounding cells such as glia cells. Protein nitration marker 3-NT was lower in DA compared to $\mathrm{PVG}$ after $\mathrm{ONOO}^{-}$and $\mathrm{NO} . \mathrm{O}_{2}^{-}$ caused no difference in 3-NT levels between phenotypes. 3-NT is caused by nitrosylation of tyrosine residues (Beckman et al., 1990) and is found in cortical tissue in TBI (Deng et al., 2007). 3-NT was consistently increased 10$15 \times$ in $\mathrm{PVG}$ neurons after $\mathrm{NO}, \mathrm{O}_{2}^{-}$, and $\mathrm{ONOO}^{-}$. Nitrosylation therefore occurred indiscriminate of oxidant and correlated with the initial oxidative stress levels and Mn-
SOD expression, similarly to lipid peroxidation. MnSOD and PRDX5 effectively eliminate $\mathrm{O}_{2}^{-}$and $\mathrm{ONOO}^{-}$, but no specific enzyme targets NO. NO in low concentrations controls diverse physiologic functions such as cytotoxicity, cytostasis, regulation of vascular tone, inhibition of platelet aggregation and neurotransmission. In higher concentrations $\mathrm{NO}$ becomes toxic by reacting with $\mathrm{O}_{2}^{-}$to form $\mathrm{ONOO}^{-}$(O'Connell and Littleton-Kearney, 2013). A majority of inflammatory derived NO is caused by iNOS, mostly in inflammatory cells but also in neurons (Günther et al., 2012). It is possible that oxidative stress leads to direct neuronal iNOS induction, which would add to the oxidative insult and the neurotoxicity. iNOS expression was therefore investigated and was not induced by $\mathrm{ONOO}^{-}, \mathrm{NO}, \mathrm{O}_{2}^{-}$, or 4-HNE in either DA or PVG. It is likely that de novo synthesis required inflammatory networks and that isolated oxidative stress alone was not sufficient for neuronal iNOS induction.

Factors limiting the extrapolation of results to the in vivo situation includes the use of higher $\mathrm{O}_{2}$ and $\mathrm{CO}_{2}$ tensions in cell cultures compared to in vivo, which may influence how cells respond to oxidative stress. Moreover, the study involved a single cell type which may react differently in vivo, in a context with surrounding cells in the brain such as glia, endothelium and immune cells. Nevertheless, a reductionist approach was necessary to test the hypothesis of phenotypic differences in nerve cells specifically. Neurons from both strains were treated identically and reacted differently why results should be regarded as proof of concept while not directly transferable to how neurons perform in vivo. Earlier studies of knockout animals have established that manipulating specific enzymes may affect the redox balance (Holley et al., 2011). We have used an alternative approach to test genetic control of oxidative insults. Our study presented novel findings of genetic control of redox processes, in inbred and not engineered genomes. Knock-out models may be difficult to interpret and do not represent spontaneously generated systems; conditional knock-out of MnSOD in postnatal neurons in mice did not increase oxidative damage (Misawa et al., 2006). Furthermore, our 
study provides a systems approach to the inflammatory challenge and its potential to cause neuronal death. The experimental rats responded with higher iNOS and $\mathrm{Mn}$ SOD levels in the PVG strain (Günther et al., 2012) while isolated neuronal cultures in this study showed a different response when the systems were reduced to individual cells: now DA rats responded with early inflammatory markers and higher MnSOD-levels, while PVG rats were actually more susceptible to the challenges, produced more 3-NT and produced higher levels of LDH as markers of cellular death. Taken together, the findings provided a model to view individuals as integrated biological systems with sets of balanced responses to individual inflammatory stimuli; a systems view that is used for studies of the immune system (Aderem and Smith, 2004; Brodin and Davis, 2017). In this context, studies of inflammatory challenges may integrate the span from reduced single biochemical reactions to cellular reactions and intercellular interplay that form a biological totality that may better explain heterogonous and seemingly contradictory responses to trauma and treatment.

\section{Conclusion}

The neuronal antioxidative response and oxidative stress levels varied with the oxidant used, where $\mathrm{ONOO}^{-}$ was confirmed as the most powerful mediator of oxidative damage, while 4-HNE caused mild effects. 4-HNE and iNOS did not cause additional oxidative damage. DA neurons displayed a higher antioxidative response, resulting in lower oxidative stress and cell death mainly due to a stronger induction of MnSOD and not a general increase of antioxidative systems. It can be speculated if this represents an adaption of DA neurons to a more inflammation-prone environment. These findings indicate that phenotypic antioxidative regulation affects the secondary inflammation and oxidative stress in TBI, which should be considered in future individualized treatments and when evaluating antioxidative pharmacological interventions.

\section{References}

Acquaviva R, Campisi A, Murabito P, Raciti G, Avola R, Mangiameli S, Musumeci I, Barcellona ML, Vanella A, Li Volti G (2004) Propofol attenuates peroxynitrite-mediated DNA damage and apoptosis in cultured astrocytes: an alternative protective mechanism. Anesthesiology 101:1363-1371. Medline

Aderem A, Smith KD (2004) A systems approach to dissecting immunity and inflammation. Semin Immunol 16:55-67. Medline

Almeida A, Delgado-Esteban M, Bolaños JP, Medina JM (2002) Oxygen and glucose deprivation induces mitochondrial dysfunction and oxidative stress in neurones but not in astrocytes in primary culture. J Neurochem 81:207-217. CrossRef

Al Nimer F, Beyeen AD, Lindblom R, Ström M, Aeinehband S, Lidman $\mathrm{O}$, Piehl F (2011) Both MHC and non-MHC genes regulate inflammation and T-cell response after traumatic brain injury. Brain Behav Immun 25:981-990. CrossRef Medline

Al Nimer F, Lindblom R, Ström M, Guerreiro-Cacais AO, Parsa R, Aeinehband S, Mathiesen T, Lidman O, Piehl F (2013) Strain influences on inflammatory pathway activation, cell infiltration and complement cascade after traumatic brain injury in the rat. Brain Behav Immun 27:109-122. CrossRef Medline
Bains M, Hall ED (2011) Antioxidant therapies in traumatic brain and spinal cord injury. Biochim Biophys Acta 1822:675-684. CrossRef Medline

Beckman JS, Beckman TW, Chen J, Marshall PA, Freeman BA (1990) Apparent hydroxyl radical production by peroxynitrite: implications for endothelial injury from nitric oxide and superoxide. Proc Natl Acad Sci USA 87:1620-1624. Medline

Bellander BM, Lidman O, Ohlsson M, Meijer B, Piehl F, Svensson M (2010) Genetic regulation of microglia activation, complement expression, and neurodegeneration in a rat model of traumatic brain injury. Exp Brain Res 205:103-114. CrossRef

Block ML, Zecca L, Hong JS (2007) Microglia-mediated neurotoxicity: uncovering the molecular mechanisms. Nat Rev Neurosci 8:57-69. CrossRef Medline

Brodin P, Davis MM (2017) Human immune system variation. Nat Rev Immunol 17:21-29. CrossRef Medline

Dardiotis E, Fountas KN, Dardioti M, Xiromerisiou G, Kapsalaki E, Tasiou A, Hadjigeorgiou GM (2010) Genetic association studies in patients with traumatic brain injury. Neurosurg Focus 28:E9. CrossRef Medline

Deng Y, Thompson BM, Gao X, Hall ED (2007) Temporal relationship of peroxynitrite-induced oxidative damage, calpain-mediated cytoskeletal degradation and neurodegeneration after traumatic brain injury. Exp Neurol 205:154-165. CrossRef Medline

Dianzani MU (2003) 4-hydroxynonenal from pathology to physiology. Mol Aspects Med 24:263-272.

Dranka BP, Hill BG, Darley-Usmar VM (2010) Mitochondrial reserve capacity in endothelial cells: the impact of nitric oxide and reactive oxygen species. Free Radic Biol Med 48:905-914. CrossRef Medline

Dranka BP, Benavides GA, Diers AR, Giordano S, Zelickson BR, Reily C, Zou L, Chatham JC, Hill BG, Zhang J, Landar A, DarleyUsmar VM (2011) Assessing bioenergetic function in response to oxidative stress by metabolic profiling. Free Radic Biol Med 51: 1621-1635. CrossRef Medline

Faraci FM (2006) Reactive oxygen species: influence on cerebral vascular tone. J Appl Physiol 100:739-743. CrossRef Medline

Flynn JM, Melov S (2013) SOD2 in mitochondrial dysfunction and neurodegeneration. Free Radic Biol Med 62:4-12. CrossRef Medline

Günther M, Al Nimer F, Gahm C, Piehl F, Mathiesen T (2012) iNOSmediated secondary inflammatory response differs between rat strains following experimental brain contusion. Acta Neurochir (Wien) 154:689-697. CrossRef Medline

Holley AK, Bakthavatchalu V, Velez-Roman JM, St. Clair DK (2011) Manganese superoxide dismutase: guardian of the powerhouse. Int J Mol Sci 12:7114-7162. CrossRef

Ishii T, Itoh K, Ruiz E, Leake DS, Unoki H, Yamamoto M, Mann GE (2004) Role of Nrf2 in the regulation of CD36 and stress protein expression in murine macrophages: activation by oxidatively modified LDL and 4-hydroxynonenal. Circ Res 94:609-616. CrossRef Medline

Jones TR, Kang IH, Wheeler DB, Lindquist RA, Papallo A, Sabatini DM, Golland P, Carpenter AE (2008) CellProfiler analyst: data exploration and analysis software for complex image-based screens. BMC Bioinformatics 9:482. CrossRef Medline

Jordan BD (2007) Genetic influences on outcome following traumatic brain injury. Neurochem Res 32:905-915. CrossRef Medline

Kalogeris T, Bao Y, Korthuis RJ (2014) Mitochondrial reactive oxygen species: a double edged sword in ischemia/reperfusion vs preconditioning. Redox Biol 2:702-714. CrossRef

Kruman II, Mattson MP (1999) Pivotal role of mitochondrial calcium uptake in neural cell apoptosis and necrosis. J Neurochem 72: 529-540. Medline

Lambert AJ, Brand MD (2009) Reactive oxygen species production by mitochondria. Methods Mol Biol 554:165-181. CrossRef Medline

Lu J, Goh SJ, Tng PY, Deng YY, Ling EA, Moochhala S (2009) Systemic inflammatory response following acute traumatic brain injury. Front Biosci 14:3795-3813. Medline 
Lundberg C, Lidman O, Holmdahl R, Olsson T, Piehl F (2001) Neurodegeneration and glial activation patterns after mechanical nerve injury are differentially regulated by non-MHC genes in congenic inbred rat strains. J Comp Neur 431:75-87. Medline

Maas Al, Menon DK (2012) Traumatic brain injury: rethinking ideas and approaches. Lancet Neurol 11:12-13. CrossRef Medline

Malecki A, Garrido R, Mattson MP, Hennig B, Toborek M (2000) 4-Hydroxynonenal induces oxidative stress and death of cultured spinal cord neurons. J Neurochem 74:2278-2287. Medline

McAllister TW (2010) Genetic factors modulating outcome after neurotrauma. PM R 2:S241-S252. CrossRef Medline

Misawa H, Nakata K, Matsuura J, Moriwaki Y, Kawashima K, Shimizu T, Shirasawa T, Takahashi R (2006) Conditional knockout of Mn superoxide dismutase in postnatal motor neurons reveals resistance to mitochondrial generated superoxide radicals. Neurobiol Dis 23:169-177. CrossRef Medline

Mocco J, Mack WJ, Ducruet AF, Sosunov SA, Sughrue ME, Hassid BG, Nair MN, Laufer I, Komotar RJ, Claire M, Holland H, Pinsky DJ, Connolly ES Jr (2006) Complement component C3 mediates inflammatory injury following focal cerebral ischemia. Circ Res 99:209-217. CrossRef

Morganti-Kossmann MC, Satgunaseelan L, Bye N, Kossmann T (2007) Modulation of immune response by head injury. Injury 38:1392-1400. CrossRef Medline

O'Connell KM, Littleton-Kearney MT (2013) The role of free radicals in traumatic brain injury. Biol Res Nurs 15:253-263.
Pickering AM, Vojtovich L, Tower J, Davies KJA (2013) Oxidative stress adaptation with acute, chronic and repeated stress. Free Radic Biol Med 55:109-118. CrossRef Medline

Piehl F, Lundberg C, Khademi M, Bucht A, Dahlman I, Lorentzen JC, Olsson T (1999) Non-MHC gene regulation of nerve root injury induced spinal cord inflammation and neuron death. J Neuroimmunol 101:87-97. Medline

Reid WM, Rolfe A, Register D, Levasseur JE, Churn SB, Sun D (2010) Strain-related differences after experimental traumatic brain injury in rats. J Neurotrauma 27:1243-1253. CrossRef Medline

Szabó C, Ischiropoulos H, Radi R (2007) Peroxynitrite: biochemistry, pathophysiology and development of therapeutics. Nat Rev Drug Discov 6:662-680. CrossRef Medline

Tamm C, Zhivotovsky B, Ceccatelli S (2008) Caspase-2 activation in neural stem cells undergoing oxidative stress-induced apoptosis. Apoptosis 13:354-363. CrossRef Medline

Ten VS, Yao J, Ratner V, Sosunov S, Fraser DA, Botto M, Sivasankar B, Morgan BP, Silverstein S, Stark R, Polin R, Vannucci SJ, Pinsky D, Starkov AA (2010) Complement component c1q mediates mitochondria-driven oxidative stress in neonatal hypoxic-ischemic brain injury. J Neurosci 30:2077-2087. CrossRef Medline

Trackey JL, Uliasz TF, Hewett SJ (2001) SIN-1-induced cytotoxicity in mixed cortical cell culture: peroxynitrite-dependent and -independent induction of excitotoxic cell death. J Neurochem 79:445-455. Medline

Uchida K (2003) 4-Hydroxy-2-nonenal: a product and mediator of oxidative stress. Prog Lipid Res 42:318-343. Medline 